Wright State University

CORE Scholar

$9-2009$

\title{
Multiproxy Lake Sediment Records at the Northern and Southern Boundaries of the Aspen Parkland Region of Manitoba, Canada
}

\author{
Rebecca Teed \\ Wright State University - Main Campus, rebecca.teed@wright.edu \\ Charles Umbanhower \\ Philip Camill
}

Follow this and additional works at: https://corescholar.libraries.wright.edu/ees

Part of the Earth Sciences Commons, and the Environmental Sciences Commons

\section{Repository Citation \\ Teed, R., Umbanhower, C., \& Camill, P. (2009). Multiproxy Lake Sediment Records at the Northern and Southern Boundaries of the Aspen Parkland Region of Manitoba, Canada. The Holocene, 19 (6), 937-948. https://corescholar.libraries.wright.edu/ees/47}

This Article is brought to you for free and open access by the Earth and Environmental Sciences at CORE Scholar. It has been accepted for inclusion in Earth and Environmental Sciences Faculty Publications by an authorized administrator of CORE Scholar. For more information, please contact library-corescholar@wright.edu. 


\title{
MULTI-PROXY LAKE SEDIMENT RECORDS AT THE NORTHERN AND SOUTHERN BOUNDARIES OF THE ASPEN PARKLAND REGION OF MANITOBA, CANADA ${ }^{1}$
}

\author{
Rebecca Teed ${ }^{2}$ (rebecca.teed@wright.edu), Charles E. Umbanhowar ${ }^{3}$, \& Philip Camill ${ }^{4}$
}

\begin{abstract}
Aspen parkland in central Canada may change substantially with increased warming and aridity as prairies replace forests, fire return intervals decrease, and lake levels decline. We examined the relationships among vegetation, climate, fire, and lake-ecosystem properties using lake sediment cores from the current northern and southern boundaries of the aspen parkland in southwestern Manitoba. We analyzed pollen, charcoal, sediment magnetics, biogenic silica, phosphorus, grain size, and LOI, and dated the cores using 210Pb and 14C (AMS, calibrated). The Jones Lake record, from the southern edge of the parkland, began considerably earlier ( $11,000 \mathrm{cal}$ BP) than the Mallard Pond record at the northern edge ( 8,600 cal BP). These sites were characterized as prairie communities with low fire severity and relatively low lake productivity during the warm, dry period from 9,000-6,000 cal BP. Beginning around 6,500 cal BP at Jones Lake and 3,400 cal BP at Mallard Pond, conditions appeared to get wetter as indicated by arboreal pollen percentage increases from $~ 30 \%$ to $40-60 \%$ concurrent with a rise in charcoal and proxies for lake productivity (biogenic silica and percent organic phosphorus). Similar to previous studies along the prairie-forest border, we found that charcoal increased during warmer, wetter periods with increased forest cover and fuel loading rather than during warmer, drier periods of prairie dominance. Our results underscore the importance of regional changes in moisture, and its effects on lake levels and forest biomass, as a dominant control of the aspen parkland dynamics.
\end{abstract}

Key words: Aspen parkland, pollen, charcoal, ecotone, prairie-forest border, Canada

\section{INTRODUCTION}

The aspen parkland vegetation zone in Canada represents a climatically sensitive region where a combination of temperature, effective moisture, and fire control the dynamics of the boreal ecotone to the north and the grassland ecotone to the south. The prairie-forest border in North America currently extends from the Gulf of Mexico north through Minnesota into Manitoba, then roughly northwest to Alberta. In the United States, this border is generally a zone of oak barrens separating tall-grass prairie from deciduous forest (Anderson, 1982; Sims and Risser, 2000). In Canada, aspen parkland runs between mixed-grass prairie and boreal

\footnotetext{
${ }^{1}$ This is an Accepted Manuscript published as Teed, R., Umbanhowar, C.E. Jr., and Camill, P., Multi-proxy lake sediment records at the northern and southern boundaries of the Aspen Parkland region of Manitoba, Canada, The Holocene (vol. 19, issue 6) pp. 937-948. Copyright (C) 2009 (SAGE Publishing). DOI: [10.1177/0959683609336569].

${ }^{2}$ Wright State University, 3640 Col. Glenn Hwy, Dayton OH 45435, USA

${ }^{3}$ Department of Biology, St. Olaf College, Northfield, MN 55057 USA

${ }^{4}$ Environmental Studies Program and Department of Biology, Bowdoin College, Brunswick, ME 04011 USA
} 
forest (Scott, 1995). Both aspen parkland and oak barrens are woodlands, with partial tree cover and nearly complete herbaceous ground cover.

The modern limits of the aspen parkland correspond to climate moisture gradients (Hogg, 1994). This ecotone marks the eastern limit of late-summer drought (Transeau, 1935; Hogg, 1994; MacDonald and Case, 2000). The northern boundary, between aspen parkland and boreal forest, generally occurs where annual precipitation exceeds potential evapotranspiration. The southern boundary, between parkland and prairie, is generally the line along which potential evapotranspiration is $15 \mathrm{~cm}$ greater than annual precipitation. During the dry season, wildfires in this zone favor the spread of Populus tremuloides, which can reproduce vegetatively from sprouts and does so more vigorously after burning (Anderson and Bailey, 1980). Precipitation exceeds potential evaporation most of the year, allowing tall grasses and forbs to flourish, but moisture availability usually becomes negative by August, resulting in water stress for trees (Faben-Langendoen and Tester, 1993) and favorable conditions for fire (Transeau, 1935; Collins and Wallace, 1990; Grimm, 1984).

Given the sensitivity of parkland to changes in temperature and precipitation, increased warming and aridity may cause a transition from forest to prairie and a decline in fire return intervals and lake levels. Hogg (1994) predicts that aspen parkland is likely to expand northwards at the expense of boreal forest and to be replaced at its southern margin by grassland. However, along the southern and western edges of aspen parkland in Alberta and Saskatchewan, aspen and other parkland trees have been spreading into grassland over the last 100 to 150 years, according to both land surveys (Archibold and Wilson, 1980; Grant and Murphy, 2005) and pollen records (McAndrews, 1988; Campbell and Campbell, 2000; Campbell and Flannigan, 2000). Campbell et al. (1994) and Campbell and Campbell (2000) explain these increases as a response to near-elimination of bison populations and near-total fire suppression, both factors associated with EuroCanadian settlement, which favor aspen at the expense of prairie vegetation.

With the potential for complex interactions among climate, vegetation, and fire, there is greater need for multi-proxy records that allow assessment of these variables simultaneously. Changes in grazing, insect herbivory, and human activity, both before and after EuroCanadian settlement will complicate vegetation and fire responses even further.

The timing of shifts in the prairie-forest boundary varies geographically, as different air masses responded to changes in seasonal insolation (Webb et al., 1993). In northern Illinois, Nelson et al. (2006) found two periods of increased aridity and prairie expansion: the first from 9,000 to 7,500 years cal BP, the second after 6,000 cal BP. There is only a single period of prairie expansion in Minnesota, from roughly 8,000 to 4,000 cal BP (Camill et al., 2003; Wright et al., 2004), similar to the period of maximum aridity from $~ 8,300$ and 4,500 cal BP in the Canadian northern Great Plains (Laird et al., 2007). This warm, arid period, the Holocene Thermal 
Maximum (HTM), began in south-central Canada between 9000 cal BP $(10,200-8,500$ depending on the site) and ended about 6,000 cal BP (Anderson et al., 1989; Ritchie and Harrison, 1993; Vance et al., 1995; Laird et al., 2007). The HTM is characterized by lower lake levels regionally (Ritchie and Harrison, 1993), indicating less precipitation than present from autumn to spring (Grimm, 2001).

Studies of fossil charcoal show complex relationships between fire and vegetation. Vegetation has to be dry enough to burn in the first place but sufficiently productive and continuous to carry a fire. In the above records from the prairie/forest border in southern Minnesota (Camill et al., 2003; Umbanhowar et al., 2006) and in northern Illinois (Nelson et al., 2006), charcoal concentrations generally increase with independent measures of aridity (based on LOI and sediment-magnetic data). However, when these aridity measures decline, indicating a wetter climate, charcoal concentrations may continue to increase, as they do at Chatsworth Bog, Illinois, between 8,500 and 6,500 cal BP and Kimble and Sharkey Lakes, Minnesota, from 5,000 to $2,500 \mathrm{cal}$ BP. Some records from prairie lakes (not ecotonal) show an inverse relationship between charcoal concentrations and aridity (Clark et al., 2002; Nelson et al., 2004; Brown et al., 2005) through the entire Holocene; presumably, these ecosystems were dry enough to burn during much of the year, and fuel load was the limit factor on wildfires.

To better understand the relative influence of climate and fire on vegetation and lake dynamics in the aspen parkland region, we collected lake sediment cores from the northern edge of the aspen-parkland ecotone (the parkland/boreal transition) and the southern edge (the prairie/parkland transition) in southwestern Manitoba, Canada-a region that has not hitherto been intensively studied. We assembled multi-proxy records of pollen, charcoal, sediment magnetic, clastic grain size, biogenic silica (bSi), total and organic fractions of sediment phosphorus. We hypothesized that the timing of vegetation, fire, and lake ecosystem changes at the southern and northern boundary of this ecotone would be driven ultimately by the timing of regional changes in moisture. Increasing moisture, which should be reflected in past changes in lake productivity proxies (bSi, total $\mathrm{P}$, and organic $\mathrm{P}$ ), should cause an increase in arboreal pollen types. We predicted higher charcoal levels as a response to greater fuel availability, less complete combustion, and the possibility of crown as well as ground fires. However, it is unclear how the northern boundary of the aspen parkland (characterized by a pollen assemblage that includes Picea, Betula and Pinus) and southern boundary (characterized by a pollen assemblage rich in Quercus and herbs) will differ in their responses to climate change.

\section{STUDY AREAS}

Prior to European settlement, the dominant vegetation of the aspen parkland included grasses (Poaceae spp.), sage (Artemisia spp.), and prairie taxa, particularly Festuca scabrella (Sims and Risser, 2000), with scattered trees, mostly Populus tremuloides, Betula papyrifera and 
Pinus in the north, with some Quercus macrocarpa and other hardwoods in the south (Ritchie and Lichti-Federovich, 1968; Weir, 1983). According to Hanuta (2006), a roughly equal mix of prairie and forest was present in south-central Manitoba just prior to Euroamerican settlement.

The two lakes we studied were located in southwestern Manitoba, Canada (Fig. 1). Jones Lake $\left(49^{\circ} 26^{\prime} 47^{\prime \prime} \mathrm{N}, 99^{\circ} 17^{\prime} 28^{\prime \prime} \mathrm{W}\right)$ is about $13 \mathrm{~km}$ south of Glenboro, located on the southern margin of the aspen parkland near the border with the tall-grass prairie (Fig. 1). This site was about $20 \mathrm{~km}$ south of Lake Agassiz during the Lockhart high stand until some time before $10,800{ }^{14} \mathrm{C} \mathrm{BP}\left(12,800 \mathrm{cal} \mathrm{BP}\right.$; Boyd, 2007). Mallard Pond $\left(51^{\circ} 17^{\prime} 8^{\prime \prime} \mathrm{N}, 101^{\circ} 19^{\prime} 29^{\prime \prime} \mathrm{W}\right)$ is about $8 \mathrm{~km}$ north of Roblin, Manitoba, along the western border of the province and at the edge of the boreal forest. Water depths at the coring sites were $4.4 \mathrm{~m}$ for Jones Lake and 10.2 $\mathrm{m}$ for Mallard Pond. Jones Lake has a surface area of 56 ha while the surface area for Mallard Pond is 8.0 ha. We compared the vegetation changes in these lakes to previously published pollen records from this region, from the Glenboro site and E Lake (Fig. 1, Ritchie and LichtiFederovich, 1968; Ritchie, 1969).

Our sample sites are both located in glacial tills but extensive areas of glacio-fluvial material occur less than $2 \mathrm{~km}$ around Jones Lake and large colluvial deposits are found less than $2.5 \mathrm{~km}$ east of Mallard Pond (Matile and Keller, 2006).

\section{METHODS}

\section{Sediment retrieval and dating}

We obtained multiple overlapping cores from the deepest parts of Jones Lake in August, 2002 and March, 2003 and Mallard Pond in January and April of 2003. The top 1 meter of flocculent sediment from both lakes was collected using a clear polycarbonate piston corer and vertically extruded in 2-cm sections. The remainder of each core was collected using a modified Livingston corer (Wright et al., 1984), extruded in the field, and wrapped in polyurethane and aluminum foil for transport, and split in the lab. The sediment was stored at $4^{\circ} \mathrm{C}$. Sediment recovery at Mallard Pond was incomplete in a few parts of the core, leading to gaps in the analyses.

Age chronologies for the lake cores were established using a combination of calibrated AMS ${ }^{14} \mathrm{C}$ dating of macrofossils and ${ }^{210} \mathrm{~Pb}$ dating. Procedures for ${ }^{210} \mathrm{~Pb}$ follow a modification of the ${ }^{210} \mathrm{~Pb}$ dating method of Eakins and Morrison (1978), and both cores were analyzed at the

${ }^{210} \mathrm{~Pb}$ dating facilities at the Science Museum of Minnesota's St. Croix Watershed Research Station. Age profiles are determined using a Constant Rate of Supply (CRS) model according to the method of Binford (1990). All AMS ${ }^{14} \mathrm{C}$ samples (charcoal and/or terrestrial macrophytes) were cleaned (hand-selection and acid-base-acid rinse) and submitted to Lawrence Livermore National Laboratory for analysis. All dates were calibrated using CALIB 4.2 (Stuiver et al., 1998 and 1999) and are reported here in calendar years before present (cal BP) (Table 1). The 
sediments at each lake appear to have been almost continuously deposited in Jones Lake, starting approximately $12,000 \mathrm{cal}$ BP and Mallard Pond starting about 8,500 cal BP (Fig. 2).

\section{Sediment and lake ecosystem properties}

Sampling intensity varied with analysis. For magnetic analyses, samples were taken every $\sim 2 \mathrm{~cm}$ down each core. For other analyses, samples $0.5 \mathrm{~cm}$ thick were taken approximately every $10 \mathrm{~cm}$ down the core (representing one sample per average of 105 years of deposition at Jones Lake and an average of 164 years at Mallard Pond), except for grain size, which we sampled at $20 \mathrm{~cm}$ intervals.

We measured isothermal remanent magnetization (IRM), and anhysteretic remanent magnetization (ARM) at the Institute for Rock Magnetism at the University of Minnesota. IRM was acquired in a magnetic field of $1500 \mathrm{mT}$ and reflects the concentration of ferromagnetic minerals. ARM was acquired in a peak alternating field of $100 \mathrm{mT}$ and a bias field of $50 \mu \mathrm{T}$. All remanence parameters were measured with a cryogenic magnetometer (2G-model 760-R). ARM is strongly influenced by the presence of small single-domain (SD) and small pseudosingle-domain (PSD) particles (Hunt et al., 1995). Changes in the ratio of ARM/IRM are used to characterize the relative importance of fine SD particles vs. larger particles.

Loss-on-ignition was used to estimate the relative amounts of combustible components in the sediment (Dean, 1974). The sediment was ignited in a muffle furnace at $550^{\circ} \mathrm{C}$ to determine the organic fraction and at $1000^{\circ} \mathrm{C}$ to determine the carbonate fraction.

Percent biogenic silica from diatoms was measured to further describe the residual inorganic sediment fraction. Silica was extracted from 30-mg samples of freeze-dried sediment using a $1 \%$ solution of $\mathrm{Na}_{3} \mathrm{O}_{2}$ (Conley and Schelske 1993), and the concentrations were measured colorimetrically (McKnight 2000) using a Lachat QC 8000 FIA (Method 10-114-27-1A). Where appropriate, estimates of percentage of silica were based on the intercept of a line fit through 3, 4 and 5-hour measurements (Conley 1998).

Samples for phosphorus analysis were freeze-dried and lightly ground, and extracted using procedures described by Engstrom and Wright (1984). Total phosphorus (TP) extraction was based on digests of $\sim 0.1$-g in $30 \% \mathrm{H}_{2} \mathrm{O}_{2}$ for $\sim 1$ hour at $90^{\circ} \mathrm{C}$ and subsequent acidification with $2.5-\mathrm{N} \mathrm{HCl}$. Inorganic $P$ was extracted by shaking sediment samples $(0.1 \mathrm{~g})$ in $10 \mathrm{ml}$ of $0.5 \mathrm{~N}$ $\mathrm{HCl}$ for 16 hrs. Extracted-P was analyzed colorimetrically using a Lachat Method 10-115-01-1-B. Organic-P was calculated as TP - Inorganic P and is shown as a percentage of TP.

To analyze grain size of siliceous particles, we prepared samples by heating $\sim 3.0 \mathrm{~g}$ of sediment in $10 \% \mathrm{HCl}$ for $15 \mathrm{~min}$. Sediments were then digested in $30 \% \mathrm{H}_{2} \mathrm{O}_{2}$ for 30 min (or until reaction ceased), and two $\mathrm{mL}$ of $11-\mathrm{M} \mathrm{HNO}_{3}$ were added for $10 \mathrm{~min}$. The samples were rinsed into centrifuge tubes with deionized water and methanol, and centrifuged at 4,500 rpm for 15 minutes. In order to minimize loss of sediment after rinsing, the supernatant was removed from 
the tubes using a sipper apparatus instead of being decanted (modified from Triplett, 2002). Processed sediment was frozen until analysis, and grain size was measured using a Horiba LA920 particle analyzer.

\section{Pollen analysis}

Pollen preparation and identification were done according to the methods of Faegri et al. (1989) and identifications were confirmed using a reference collection derived from that of Dr. E.J. Cushing (University of Minnesota). A minimum of 300 terrestrial pollen grains or spores was counted for each level (with one exception: a total of 274 grains). Levels with very low pollen concentrations were excluded from the dataset.

The sediment record was divided into zones of similar assemblages of terrestrial pollen types that are at least $5 \%$ of the total sum of terrestrial pollen and spore types for at least one level by psimpoll (Bennett, 1994), which uses algorithms from Birks and Gordon (1985). Visible changes in the pollen diagram matched the zone boundaries determined by psimpoll through optimal (non-binary) splitting of the information content of the pollen percentages. Zone boundaries were chosen that reduced the total variance (in common pollen types) by a statistically significant amount, indicating major changes in vegetation.

Pollen assemblages within a given zone are considered to have been deposited by the same vegetation type. Ecosystems are identified statistically in this analysis, through simultaneous changes in common types in assemblages, rather than by the presence or absence of a single marker. Populus pollen in particular seemed to be a poor choice for a marker, because it tends to be underrepresented relative to the basal area of the parent tree compared to pollen of other wind-pollinated tree types (Lee et al., 1996). At Jones Lake, Populus is a rare pollen type, generally $<1 \%$, even in assemblages from the surface sediments, although the lake is surrounded by modern aspen parkland (Fig. 3 and 5).

Although both sites are in areas that have been cleared and are intensively farmed, the pollen assemblages in the surface sediments strongly resemble those that have been deposited over at least the past thousand years. The residual parkland vegetation still contributes far more of the regional pollen rain than the insect-pollinated crops and weeds associated with modern Great Plains agriculture. Therefore, the assemblages of the top zone are interpreted as aspen parkland (somewhat different types at the northern and southern edge), with vegetation similar to the aspen parkland known to flourished in each place hundreds of years ago (Weir, 1983; Scott, 1995).

\section{Charcoal analysis}

Charcoal was sieved from $1.0-\mathrm{cm}^{3}$ sediment samples using a $180-\mu \mathrm{m}$ screen, and the area of each particle was measured at 20x magnification using image-analysis software (Clark and Hussey, 1996). Charcoal influx was calculated by multiplying the charcoal concentration by 
the sediment accumulation rate derived from the age model (Fig. 2). The analysis methods for magnetic properties, pollen, charcoal, and biogenic silica are also described in Camill et al. (2003).

\section{RESULTS}

Using the palynological zonation, we compared changes in vegetation in each of the zones to changes in sediment, lake-ecosystem, and fire proxies (magnetics, bSi, total and organic $\mathrm{P}, \mathrm{LOI}$, and grain size and charcoal). Below, we present a chronological analysis of each zone for both lakes.

\section{Jones Lake}

J1 (11,150 - 10,400 cal BP): The basal assemblages of J1 contain high percentages of Picea pollen ( 80\%), indicating a closed-canopy forest, with a little Betula, Poaceae, Cyperaceae, and Artemisia ( $5 \%$ ) and traces of other prairie types (Fig. 3). Picea pollen percentages decline as those of Pinus pollen increase (to $10 \%$ ) at the top of the zone. Traces of Populus pollen are visible throughout the record, but often as a single grain, which may have been carried to the lake from far away by wind.

Sediment proxies indicate recent glacial retreat from the area and the erosional deposition of glacial silts (Fig. 4). IRM and ARM/IRM reach maxima of $0.71 \mathrm{~A} \mathrm{~m}^{-1}$ and 0.12 (with the exception of a single ARM/IRM peak at the top of the core) indicating abundant, finegrained magnetic material consistent with glacial silts. Alternatively, deeper water ( $15 \mathrm{~m}, 5 \mathrm{~m}$ deeper than present) (Fig. 2), combined with trees to block winds, may have resulted in anoxic conditions that favored magnetotactic bacteria that produce single-domain magnetic grains (Geiss et al., 2004). However, anoxia in the sediments also speeds dissolution of those magnetic minerals.

The sediment is relatively rich in organic matter ( $25 \%)$ and bSi is at its highest $(\sim 10 \%)$ in this zone. Sedimentation rates were low (Fig. 2), and mean grain size of clastics ( $18 \mu \mathrm{m})$ is similar to other zones. TP concentrations ( $\sim 0.75 \mathrm{mg} \mathrm{gm}-1)$ are relatively high, but low OP ( 20\%) suggests generally low lake productivities. Charcoal concentration $\left(\sim 1 \mathrm{~mm}^{2} \mathrm{~cm}^{-3}\right)$ and influx ( $\left.0.05 \mathrm{~mm}^{2} \mathrm{~cm}^{-2} \mathrm{yr}^{-1}\right)$ were uniformly low during this period.

J2 (10,400 - 9,100 cal BP): Picea pollen percentages decline to less than $5 \%$ early in the zone as Pinus pollen rapidly increases to $20-40 \%$ of the total pollen assemblage. Quercus, Betula, Ulmus, and other hardwood pollen types are continuously present (mostly in small amounts) from this point upwards, suggesting that these thermophilous taxa were now present in the regional vegetation, and that the climate was warming. It was getting drier as well; as indicated by the increase in pollen from Poaceae (up to $38 \%$, the maximum for the Jones Lake record) and other herbs (Fig. 3). 
IRM ( 0.15 $\mathrm{A} \mathrm{m}^{-1}$ ) and ARM/IRM ( 0.05) are both lower than in zone J1, indicating reduced concentrations and overall relatively larger magnetic particles, perhaps as the result of reduced erosion of glacial silts (Fig. 4). Mean grain size of clastics drops slightly at the base of the zone, suggesting reduced surface erosion rates in the area around the lake or a shift to more windborne material. Carbonates are at their most abundant in this zone ( $35 \%)$, perhaps due to a shift to greater deposition of fine wind-borne material or increased water temperatures causing greater in-lake precipitation. BSi decreases to $~ 8 \%$, TP levels remain virtually unchanged, and OP increases slightly to $30 \%$, suggesting that the lake remained largely unproductive. There is no charcoal present in this zone, although there may have been fires; they simply left nothing behind.

J3 (9,100-6,300 cal BP): Poaceae pollen and pollen from other prairie taxa dominate this zone, especially Ambrosia (15-20\%), Artemisia (15-20\%), and Chenopodiineae (5-12\%), suggesting a shift to warmer, drier grassland conditions (Fig. 3). There are substantial amounts of Pinus pollen (20-40\%) as well, but this may have been derived from small stands, especially near lakes, streams, or other fire breaks, and some of it may have blown in from distant forests. Picea pollen is still present, but in small amounts ( $2 \%)$ for the rest of the record, but it too may have come from distant forests or small, isolated stands of trees.

IRM $\left(0.1 \mathrm{~A} \mathrm{~m}^{-1}\right)$ remains relatively constant until it declines by nearly half at $\sim 6,400 \mathrm{cal}$ BP (Fig. 4). Because ARM/IRM does not decline markedly, indicating fewer magnetic particles but of the same size. The siliceous fraction of the inorganic matter is dominated by fine siltsized particles $(15 \mu \mathrm{m})$, likely from wind-borne material. BSi ( 10\%) increases ( 7,800 cal BP) during this period but organic matter, TP, and OP remain relatively unchanged, suggesting continued low lake productivity. Charcoal concentration $\left(\sim 0.5 \mathrm{~mm}^{2} \mathrm{~cm}^{-3}\right)$ and influx $\left(\sim 0.05 \mathrm{~mm}^{2}\right.$ $\mathrm{cm}^{-2} \mathrm{yr}^{-1}$ ) remain low.

Craine and McLauchlan (2004) interpret Ambrosia pollen increases accompanied by decreases in Poaceae and charcoal as a response to intensive grazing rather than to aridity. But, they also predict patches of bare ground in grazed areas, which would lead to an increase in coarse siliceous particles deposited in Jones Lake, the opposite of what we observed. Therefore, we interpret the dominance of prairie taxa at Jones Lake as a response to HTM aridity.

Ambrosia is favored by hot, wet summers, but these can be interspersed with dry ones (Grimm, 2001), which will permit grass fires and discourage the spread of trees.

J4 (6,300 - 2,450 cal BP): Poaceae pollen percentages increase (20-25\%) as those of Ambrosia (15\%-5\%) decline early in the zone. Chenopodiineae and Pinus pollen percentages decrease gradually. Quercus and Betula pollen percentages increase early in this zone to 7\% and $\sim 3 \%$ respectively, indicating that trees started to invade the prairie, possibly as conditions became more humid (Fig.3). 
Sediment and fire proxies indicate that terrestrial and aquatic landscapes were becoming more productive (Fig. 4). Average IRM and ARM/IRM levels remain constant. Percent organic matter nearly doubles ( $15 \%)$, which, in combination with higher bSi ( 10\%), peaking at 5,500 cal BP, increased TP ( 0.75 $\left.\mathrm{mg} \mathrm{gm}^{-1}\right)$ and OP ( 40\%), suggests major increases in lake productivity, perhaps associated with warmer temperatures or higher lake levels. Grain size of terriginous materials increases and is more variable ( $10-45 \mu \mathrm{m})$, reflecting inputs of fine sands, perhaps as a result of rising lake levels but more likely associated with extended dry periods that resulted in extensive movements of dunes in SW Manitoba at roughly the same period (Wolfe et al., 2000; Running et al., 2002). The combination of increased terriginous inputs and increased productivity was responsible for doubling the sedimentation rate for the lake beginning $\sim 5,500$ cal BP. Macroscopic charcoal concentration $\left(\sim 2 \mathrm{~mm}^{2} \mathrm{~cm}^{-3}\right)$ and influx $(\sim 0.35$ $\left.\mathrm{mm}^{2} \mathrm{~cm}^{-2} \mathrm{yr}^{-1}\right)$ increased throughout the zone, especially after $\sim 4,000$ cal BP, indicating greater biomass and fuel loading.

J5 (2,450 cal BP - present): Quercus pollen percentages increase from 15\% to 30\% of all terrestrial pollen as the vegetation of the area changed from prairie to woodland (Fig. 3). Although Populus pollen percentages are very low in these assemblages, their resemblance to the surface assemblage indicates that the woodland in question is aspen parkland similar in composition to that growing in the area today. Since Populus pollen is a rare type at Jones Lake, its percentages were not used to define zones for that record. There is no sign of an Ambrosia or Salsola peak in $\mathrm{J} 5$ of the sort found in the Midwestern US at the start of intensive agriculture (Brugam, 1978; Jacobson and Engstrom, 1989), although the area around the lake is currently intensively grazed.

Sediment and fire proxies indicate a shift towards less arid conditions (Fig. 4). IRM decreases to $0.04 \mathrm{~A} \mathrm{~m}^{-1}$, and ARM/IRM changes little from zone J4, except for the top level, where the value is by far greatest in the core (it is not shown on the diagram: 0.87). The decrease in IRM may be partly due to dilution by increasing amounts of organic matter ( 20\%). BSi decreases slightly during this period to an average of $4 \%$, but TP remains relatively high $\left(\sim 0.9 \mathrm{mg} \mathrm{gm}^{-1}\right)$, and OP increases to $\sim 50 \%$, suggesting continued high lake productivity. The decrease in bSi may also be due to dilution effects or to a shift in the composition of the primary producers (blue-green algae for example) not captured by our proxies. The decrease in the size of terriginous material $(\sim 20 \mu \mathrm{m})$ and reduced sedimentation rate (Fig. $2 a$ ) likely reflect a decrease in sediment input resulting from eolian activity (Wolfe et al., 2000; Running et al., 2002) as dunes and other open areas became vegetated.

Charcoal concentrations $\left(\sim 7.5 \mathrm{~mm}^{2} \mathrm{~cm}^{-3}\right)$ and influx $\left(\sim 1.0 \mathrm{~mm}^{2} \mathrm{~cm}^{-2} \mathrm{yr}^{-1}\right)$ increase after 2,000 cal BP, coinciding with increasing arboreal pollen percentages (mainly Quercus) and decreasing herbaceous percentages (Fig. 3). As for results found previously (Camill et al., 2003), these data suggest that fire was likely responding to vegetation productivity, fuel loading, and 
decreasingly arid conditions. Fires had more fuel to burn and, if that fuel were wetter, it would combust less completely, leaving more charcoal behind.

\section{Mallard Pond}

M1 (8,600-5,100 cal BP): The basal sediments in Mallard Pond reflect conditions similar to the warm, dry zones J2-J3 in the Jones Lake record (Fig. 5). M1 has moderate percentages of Pinus pollen (>20\%), and little Picea or hardwood pollen. There are high percentages of Poaceae pollen and that of other herbs, particularly Cyperaceae and Artemisia (individually 10-20\%), and Chenopodiineae and Asteraceae subfam. Asteroideae ( $\sim 5 \%)$. Ambrosia pollen percentages are much lower than in zone J-3 at Jones Lake, possibly indicating cooler summers (Grimm, 2001). These data suggest that the region around Mallard Pond was prairie, perhaps with enough scattered stands of Pinus to be called a woodland. Moderate levels of Myriophyllum pollen were present in these assemblages ( $5 \%)$.

Sediment and fire proxies support the inference of warmer, drier conditions drawn from the pollen record (Fig. 6). The concentration of magnetic minerals is, on average, highest during this zone with IRM averaging $4.5 \mathrm{~A} \mathrm{~m}^{-1}$, and ARM/IRM is at its lowest ( $\sim 0.02$ ), indicating the presence of relatively large magnetic grains. The magnetics, combined with abundant inorganic material ( 70\%) and relatively coarse terriginous material $(15.5 \mu \mathrm{m})$, suggest that erosion of glacial silts from the surrounding uplands was prevalent until at least 7,500 cal BP, which would require at least some patches of bare ground in certain seasons.

Relatively low percentages of organic matter ( 15\%), bSi ( 2\%), and TP ( 1.0 $\left.\mathrm{mg} \mathrm{gm}^{-1}\right)$ values suggest low productivity, yet bSi and organic matter increased by $50 \%$ or more during this period. OP is $\sim 35 \%$ but declines at $\sim 5,200$ cal BP. Charcoal concentration $\left(\sim 2.5 \mathrm{~mm}^{2} \mathrm{~cm}^{-3}\right)$ and influx $\left(\sim 0.10 \mathrm{~mm}^{2} \mathrm{~cm}^{2} \mathrm{yr}^{-1}\right)$ were moderately high and increased throughout M1.

M2 (5,100-3,400 cal BP): Pinus pollen (<20\%) percentages decrease as those of Betula ( 10\%) increase (Fig. 5). Pollen percentages from prairie-type plants remain high, and Quercus and Alnus percentages increased (although remaining less than $5 \%$ ). There is also a large increase in Myriophyllum percentages (equal to $20 \%$ of the total terrestrial pollen) and a peak of Typha pollen in mid-zone, indicating a decrease in lake level that increased the littoral area, because North American Myriophyllum species tend to grow sparsely in water more than $1 \mathrm{~m}$ deep (Aiken et al., 1979). Overall, the relative abundance of arboreal vs. herbaceous taxa became much more variable. The pollen record suggests that this period was characterized by increasingly variable moisture during a shift to warm, but wetter conditions.

IRM ( 0.10 $\mathrm{A} \mathrm{m}^{-1}$ ) and ARM/IRM ( 0.03) fluctuate little but remain relatively low (Fig. 6). Mean grain size is lower than in $\mathrm{M} 1(\sim 7.5 \mu \mathrm{m})$ and declines slightly at the top of M2. Carbonates are at their highest ( $27 \%)$, perhaps in response to warming conditions. BSi ( $2.5 \%)$ is low during this zone but increases by about $50 \%$ at $\sim 4,500$ cal BP, approximately the same time that 
the sedimentation rate increased, suggesting higher productivity. Charcoal concentration ( 0.5 $\left.\mathrm{mm}^{2} \mathrm{~cm}^{-3}\right)$ and influx $\left(\sim 0.03 \mathrm{~mm}^{2} \mathrm{~cm}^{-2} \mathrm{yr}^{-1}\right)$ are low, because, as the pollen data suggest, there was little fuel for fires (Fig. 5).

M3 (3,400-1,550 cal BP): Percentages of all tree and shrub pollen types increase at the base of M3, but fluctuate, as they did during M2: Picea pollen increases to almost 5\%, Pinus to $\sim 20 \%$, and Betula to $20-40 \%$ (Fig. 5). Other arboreal pollen types continuously present include Populus, Quercus, Salix, and Alnus. Herbaceous pollen percentages decrease but only down to 40-50\%. These data suggest that Mallard Pond was surrounded by woodland. The high percentages of Populus indicate that this woodland was aspen parkland, although of a different composition from that in zone J4, with higher percentages of tree pollen types, especially Populus, Picea, and Betula, but lower percentages of Quercus. Myriophyllum pollen percentages also decline, suggesting increasing water levels.

Sediment and fire proxies suggest that, like zone J4 in Jones Lake, this zone was characterized by warm, but wetter, conditions (Fig. 6). IRM increases slightly $\left(\sim 0.15 \mathrm{~A} \mathrm{~m}^{-1}\right)$ from the previous zone, and ARM/IRM ( 0.045) almost doubles at the base of the zone and fluctuates considerably throughout, indicating a shift toward finer magnetic particles, possibly produced by magnetotactic bacteria or the episodic addition of fine-grained minerals as also suggested by fluctuations evident in the percent of organic matter ( $18 \%)$. Terriginous grain size $(\sim 7 \mu \mathrm{m})$ increases gradually through the period but varies relatively little. Biogenic silica $(\sim 4 \%)$ again nearly doubles, and both TP $\left(\sim 1.16 \mathrm{mg} \mathrm{gm}^{-1}\right)$ and OP ( 35\%) increase substantially, reflecting more productive lakes and possibly higher water tables. Charcoal concentration ( 2 $\left.\mathrm{mm}^{2} \mathrm{~cm}^{-3}\right)$ and influx $\left(\sim 0.3 \mathrm{~mm}^{2} \mathrm{~cm}^{-2} \mathrm{yr}^{-1}\right)$ increased gradually and became more variable in response to the available fuel load (Fig. 5).

M4 (1,550 cal BP - present): Picea and Populus pollen percentages increase in M4 (Fig. 5). Myriophyllum and Betula pollen percentages decrease while Poaceae, Cyperaceae, and Chenopodiineae pollen percentages increase near the base of the zone. Mallard Pond is at the border between the modern boreal forest and the aspen parkland, but little spruce grows right near the lake. Again, the similarity of the assemblages that define this zone to the modern assemblage at the top of the core imply that they were all produced by aspen vegetation much like that of the area today.

Myriophyllum pollen percentages are variable in this zone, with peaks over $60 \%$, possibly indicating changes in lake level. One of these peaks is in an assemblage deposited about $800 \mathrm{cal}$ BP, so the pollen must have come from $M$. exalbescens or $M$. verticillatum, one of the native milfoils. Neither of these has been observed undergoing large and abrupt population increases that characterize the Eurasian invader M. spicatum in historic times, but the three types are closely related (Aiken et al., 1979). Presumably, uncolonized shallow-water habitat 
became available when lake levels rose, and a native milfoil was able grow densely and to flower abundantly. These populations declined sharply at times when lake levels fell.

Sediment and fire proxies were consistent with cooler, wetter conditions at this time (Fig. 6). IRM ( 0.3 A m $\mathrm{m}^{-1}$ ) doubles at $\sim 1,000$ cal BP. At the same time, the increased ratio of ARM/IRM ( 0.05), combined with little change in size of terriginous particles until 200 cal BP, suggests increasing activity of magnetotactic bacteria. LOI carbonate and organic sediment percentages remain little changed. BSi ( 4\%) remains relatively high in this zone. TP ( $2.5 \mathrm{mg}$ $\mathrm{gm}^{-1}$ ) more than doubles, although OP does not show a similar increase. The absence of an increase in organic sediment, BSi, or OP is puzzling in light of the increase in TP, and suggests other factors may have limited productivity or increased decomposition rates.

\section{DISCUSSION}

The modern vegetation around Mallard Pond is somewhat different from that surrounding Jones Lake, although both are aspen parkland. These differences are reflected in pollen in the surface layers of each core; M4 has more Populus pollen, typical of the nearby boreal forest, and J-5 has more Quercus pollen (presumably derived from Quercus macrocarpa which grows more abundantly near the prairie-parkland border).

Despite differences in community composition, the southern and northern boundaries of the aspen parkland in Manitoba responded strongly to changes in moisture. Climatic changes and corresponding ecosystem shifts apparently occurred in two steps: a shift to relatively more mesic conditions beginning $\sim 6,400$ cal BP, followed by another increase in moisture after $\sim 2,500-3,500$ cal BP. It is possible that the first increase in moisture allowed more trees to grow in protected sites, whereas the second allowed tree populations to expand into less-protected areas. Changes in the seasonality of precipitation probably had more of an effect on the local environment than changes in the average annual amount of precipitation.

Both lakes showed a dominance of prairie taxa during the Holocene Thermal Maximum, which occurred $\sim 9,000-6,000$ cal BP in this region (Anderson et al., 1989; Ritchie and Harrison, 1993; Vance et al., 1995; Laird et al., 2007). Beginning around 6,400 cal BP at Jones Lake, conditions likely became wetter as indicated by increases in arboreal pollen percentages concurrent with an increase in charcoal (suggesting greater terrestrial biomass and fuel loading) and proxies for lake productivity (biogenic silica and organic phosphorus), but the corresponding changes at Mallard Pond 5,100 cal BP reflect more variable moisture availability, which presumably restricted tree/shrub growth, in turn reducing the amount of charcoal left by fires (Figs 3-6). If the regional increase in precipitation at the end of the HTM was primarily in the fall, winter, and spring months, there may have been a greater effect on the vegetation at the southern edge of the aspen parkland than at the northern edge. The southern part would have received a greater proportion of its winter precipitation as rain rather than as snow 
compared to the northern edge, resulting in relatively greater contributions to soil moisture than to runoff.

However, parkland replaced prairie in the Mallard Pond record about 1,000 years earlier $(\sim 3,500$ cal BP) than at Jones Lake ( 2,500 cal BP). The more arid conditions of the HTM may have persisted longer at the southerly Jones Lake site. Alternatively, frequent grass fires may have prevented aspen parkland establishment around Jones Lake without leaving much charcoal.

Similar to previous vegetation-history studies of ecotones between prairie and forest biomes, we found that charcoal increased during wetter periods with increased tree cover and fuel loading rather than during drier periods of prairie dominance (Camill et al., 2003; Nelson et al., 2006; Clark et al., 2002). Fire frequency is partly a function of precipitation and potential evaporation, but charcoal, the basis of our estimates of fire frequency, is also affected by the amount of fuel and how thoroughly it can be combusted (Umbanhowar and McGrath, 1998). The vegetation at Jones Lake and Mallard Pond is probably not changing as part of a direct response to climate but rather in response to changes in fire frequency and the amount of vegetation burned.

There have been several attempts to synthesize the origin and history of aspen parkland. Strong and Hills (2005) identify aspen parkland as a distinct ecosystem since $8,000{ }^{14} \mathrm{C}$ BP in southwestern Manitoba. They define aspen parkland as "a grassland pollen group" with a minimum Populus pollen percentage of $0.5 \%$. They amalgamated pollen counts within 1000 year increments, effectively increasing pollen count size and reducing random variation in the number of grains counted for rare types. At both Jones Lake and Mallard Pond, the zones categorized as aspen parkland, (J5, M3, and M4), are described as woodland rather than grassland, because their arboreal pollen percentages are generally over $40 \%$, and because there are scattered stands of trees growing in the remaining natural areas of the modern aspen parkland, including those around Jones Lake and Mallard Pond.

Our work supports the earlier analyses of pollen records from this area by Ritchie (1969) and Ritchie and Lichti-Federovich (1968). Their chronologies are based on radiocarbon dates from bulk sediment rather than AMS. Bulk sediment samples may include older carbon from soils and sediments in the lake's watershed (Cohen, 2003), which may be why zone transitions in the Glenboro site and E Lake occur earlier than in the Jones Lake and Mallard Pond records, particularly the older ones.

Ritchie (1969) found evidence for mid-Holocene aspen parkland at E Lake $\left(50^{\circ} 42^{\prime} \mathrm{N}\right.$, $99^{\circ} 42^{\prime} \mathrm{W}$ ) (Figs. 1, 7) in the Riding Mountain upland, which currently supports boreal forest, near the border of the modern aspen parkland. He interprets pollen assemblages from zone (c) of the $E$ Lake record as having characteristics of aspen parkland, particularly the percentages of 
Corylus, even though they lack Populus pollen (perhaps because of preservation issues). The arboreal pollen in this zone is from shrubs, mostly Alnus, Salix, and Corylus, rather than from the tree types more common in the aspen parkland zones of the Glenboro site, Jones Lake, and Mallard Pond records. The E Lake record also shows a prolonged prairie period in zone $b$, during the early Holocene, well to the north of the modern limit of prairie (Fig. 7). Ritchie and LichtiFederovich (1968) observed a pollen sequence very similar to our Jones Lake record in sediment from the Glenboro site $\left(49^{\circ} 24^{\prime} \mathrm{N}, 99^{\circ} 18^{\prime} \mathrm{W}\right)$, a few kilometers west of Jones Lake (Figs. 1 and 7).

According to our interpretation, aspen parkland became established at the northern end of its range, represented by Mallard Pond, about 3,400 cal BP and spread to the southern edge of its range around Jones Lake $2,400 \mathrm{cal} B P$, which is similar to the interpretation of Ritchie and Lichti-Federovich (1968) for the Glenboro site (Fig. 7). Before 3,400 cal BP, southwestern Manitoba was prairie with lower abundance of arboreal taxa (Figs. 3-6). This prairie was similar to the grasslands now found south of the modern aspen parkland, so during the mid-Holocene, aspen parkland, or a vegetation type with many of the same dominant species and physical features, may have flourished north of its current location or at higher elevations, and spread from there to the area around Mallard Pond as Manitoba became cooler and wetter in the late Holocene.

The interactions among climate, vegetation, fire, and grazing make interpretations of past changes challenging. Fire frequency is also affected by factors other than climate, such as human activity. Boyd (2002) proposes that fire frequency in southwestern Manitoba increased after $2,500{ }^{14} \mathrm{C}$ BP because Plains Woodland Native Americans intentionally burned areas to maintain prairie habitat for the local bison populations that they hunted. Just as in records from Alberta (Campbell et al., 1994), Populus pollen percentages for the last hundred years are highest for the entire record in both the Jones Lake and Mallard Pond cores, indicating a greater abundance of aspen in the regional vegetation. The relative contributions of changes in bison populations, human fire management strategies or land use, or climate change and attendant wildfire changes to this recent increase in aspen in southwestern Manitoba are not yet understood. However, human land use changes during the latest century may overwhelm the recent effects of climate change. Aspen itself may be spreading, but most of the area of modern aspen parkland has been converted to farmland; only about $10 \%$ remains under woodland or any other type of natural habitat (World Wildlife Fund, 1999).

\section{CONCLUSION}

Identifying the interactions among climate, vegetation, fire, and lake-ecosystem dynamics is essential for understanding how the aspen parkland ecotone will change with climate warming. With the onset of the Holocene Thermal Maximum $\sim 9,000 \mathrm{BP}$, post-glacial forests were replaced by dry prairie. Beginning around 6,400 cal BP at Jones Lake and 3,400 cal 
BP at Mallard Pond, conditions appear to get wetter as indicated by arboreal pollen percentage increases from $\sim 30 \%$ to $40-60 \%$ concurrent with an increase in charcoal and proxies for lake productivity (biogenic silica and organic phosphorus). However, lake levels at Mallard Pond appeared to fluctuate more than those of Jones Lake. Trees and shrubs became more common after $3,400 \mathrm{cal}$ BP, as the vegetation developed into aspen parkland. At Jones Lake, modern aspen parkland does not develop until 2,450 cal BP. The aspen parkland continues to change: Populus pollen is becoming more common. Our work supports previous studies of the prairieforest border indicating that wetter conditions increases tree biomass and fuel loading, which, in turn, increase fire severity. Charcoal was least abundant during warm, dry periods when this region was dominated by prairie taxa. We found that both the northern and southern parkland boundary is responsive to changes in moisture, and indicators of fire severity tend to be greatest in modern sediments.

\section{ACKNOWLEDGEMENTS}

This work was supported by National Science Foundation DEB grant 0092704 and Class of 1949 and FDE Fellowships from Carleton College and a grant to St. Olaf College from the Howard Hughes Medical Institute. We wish like to thank the landowners who permitted access to their lakes. B. Murphy, J. Dorr, L. Enlund, K. Knight, and L. Miller assisted with the field work and were essential for charcoal and magnetics analyses. Sediment magnetic analyses were conducted at the Institute for Rock Magnetism, University of Minnesota. We thank T. Brown at the Center for Accelerator Mass Spectrometry, Lawrence Livermore National Laboratory, for assisting with the $\mathrm{AMS}{ }^{14} \mathrm{C}$ dating. Alwynne Beaudoin and an anonymous reviewer made helpful comments on this manuscript. 


\section{REFERENCES}

Aiken, S. G., Newroth, P. R., and Wile, I. 1979. The Biology of Canadian Weeds. 34. Myriophyllum spicatum L. Canadian Journal of Plant Sciences 59, 201-215.

Anderson, H. G., and Bailey, A. W. 1980. Effects of annual burning on grassland in the aspen parkland of east-central Alberta. Canadian Journal of Botany-Revue Canadienne de Botanique 58, 985-996.

Anderson, R. C. 1982. The eastern prairie-forest transition an overview. Proceedings of the Eighth North American Prairie Conference. Western Michigan University, Kalamazoo, Michigan.

Anderson, T. W., Mathewes, R. W., and Schweger, C. E. 1989. Holocene climatic trends in Canada with specific reference to the Hypsithermal Interval. In Fulton, R. J., editor,

Quaternary Geology of Canada and Greenland: The Geology of North America, v. K1, Geological Survey of Canada and Geological Survey of America, 520-528.

Archibold, O. W., and Wilson, M. R. 1980. The natural vegetation of Saskatchewan prior to agricultural settlement. Canadian Journal of Botany - Revue Canadienne de Botanique $58,2031-2042$.

Bennett, K. D. 1994. 'Psimpoll' version 2.23: A C program for analysing pollen data and plotting pollen diagrams. INQUA Commission for the Study of the Holocene: Working Group on Data-Handling Methods, Newsletter 11, 4-6.

Binford, M. W. 1990. Calculation and uncertainty analysis of ${ }^{210} \mathrm{~Pb}$ dates for PIRLA project lake sediment cores. Journal of Paleolimnology 3, 253-267.

Birks, H. J. B., and Gordon, A. D. 1985. Numerical Methods in Quaternary Pollen Analysis. Academic Press.

Boyd, M. 2002. Identification of anthropogenic burning in the paleoecological record of northern prairies: A new approach. Annals of the Association of American Geographers 92, 471-487.

Boyd, M. 2007. Early postglacial history of the southern Assiniboine Delta, glacial Lake Agassiz basin. Journal of Paleolimnology 37, 313-329.

Brown, K. J., Clark, J. S., Grimm, E. C., Donovan, J. J., Mueller, P. G., Hansen, B. C., and Stefanova, I. 2005. Fire cycles in North American interior grasslands and their relation to prairie drought. Proceedings of the National Academy of Sciences of the United States of America 102, 8865-8870. 
Brugam, R. B. 1978. Human disturbance and the historical development of Linsley Pond. Ecology 59, 19-36.

Campbell, C., Campbell, I. D., Blyth, C. B., and McAndrews, J. H. 1994. Bison extirpation may have cause aspen expansion in western Canada. Ecography 17, 360-362.

Campbell, I. D., and Campbell, C. 2000. Late Holocene vegetation and fire history at the southern boreal forest margin in Alberta, Canada. Palaeogeography, Palaeoclimatology, Palaeoecology 164, 263-380.

Campbell, I. D., and Flannigan, M. D. 2000. Long-term perspectives on fire-climate-vegetation relationships in the North American boreal forest. In Kasischke, E. S., and Stocks, B. J., editors, Fire, Climate Change, and Carbon Cycling in the Boreal Forest: Ecological Studies 138, Springer, 151-172.

Camill, P., Umbanhowar, C. E. Jr., Teed, R., Geiss, C. E., Aldinger, J., Dvorak, L., Kenning, J., Limmer, J., and Walkup, K. 2003. Late-glacial and Holocene climatic effects on fire and vegetation dynamics at the prairie-forest ecotone in south-central Minnesota. Journal of Ecology 91, 822-836.

Clark, J. S., Grimm, E. C., Donovan, J. J., Fritz, S. C., Engstrom, D. R., and Almendinger, J. E. 2002. Drought cycles and landscape responses to past aridity on prairies of the northern Great Plains, USA. Ecology 83, 595-601.

Clark, J. S., and Hussey, T. C. 1996. Estimating the mass flux of charcoal from sedimentary records: effects of particle size, morphology, and orientation. The Holocene 6, 19-29.

Cohen, A. S. 2003. Paleolimnology: The History and Evolution of Lake Systems, Oxford University Press.

Collins, S. L., and Wallace, L. L. 1990. Fire in North American Tallgrass Prairies. University of Oklahoma Press.

Conley, D. J. 1998. An interlaboratory comparison for the measurement of biogenic silica in sediments. Marine Chemistry 63: 39-48.

Conley, D. J., and Schelske, C. L. 1993. Potential role of sponge spicules in influencing the silicon biogeochemistry of Florida lakes. Canadian Journal of Fisheries and Aquatic Science 50, 296-302.

Craine, J. M., and McLauchlan, K. K. 2004. The influence of biotic drivers on North American paleorecords: alternatives to climate. The Holocene 14, 787-791.

Dean, W. E. Jr. 1974. Determination of carbonate and organic matter in calcareous sediments and sedimentary rocks by loss-on-ignition: comparison with other methods. Journal of Sedimentary Petrology 44, 271-272. 
Eakins, J. D., and Morrison, R. T. 1978. A new procedure for the determination of ${ }^{210} \mathrm{~Pb}$ in lake and marine sediments. International Journal of Applied Radiation and Isotopes 29, 531536.

Engstrom, D. R., and Wright, H. R. Jr. 1984. Chemical stratigraphy of lake sediments as a record of environmental change. In Haworth, E. Y., and Lund, J. W. G., editors, Lake sediments and environmental history, University of Minnesota Press, 11-67

Faben-Langendoen, D., and Tester, J. 1993.Oak mortality in sand savannas following drought in east-central Minnesota. Bulletin of the Torrey Botanical Club 120, 248-256.

Faegri, K., Iversen, J., Kaland, P. E., and Kryzywinski, K. 1989. Textbook of Pollen Analysis, $4^{\text {th }}$ Ed. John Wiley and Sons.

Geiss, C. E., Banerjee, S. K., Umbanhowar, C. E. Jr., and Camill, P. 2004. Sediment-magnetic signature of land use and drought as recorded in lake sediment from south-central Minnesota, USA. Quaternary Research 62, 117-125.

Grant, T. A., and Murphy, R. K. 2005. Changes in woodland cover on prairie refuges in North America, USA. Natural Areas Journal 24, 359-368.

Grimm, E. C. 1984. Fire and other factors controlling the Big Woods vegetation of Minnesota in the mid-nineteenth century. Ecological Monographs 54, 291-311.

Grimm, E., ed. 1999. North American Pollen Database and Global Pollen Database. NOAA/NGDC Paleoclimatology Program. http://www.ngdc.noaa.gov/paleo/.

Grimm, E. C. 2001. Trends and Palaeoecological problems in the vegetation and climate history of the northern Great Plains, U.S.A. Biology and Environment: Proceedings of the Royal Irish Academy 101B, 47-64.

Hanuta, I. 2006. Land cover and climate for part of southern Manitoba: a reconstruction from Dominion Land Survey maps and historical records of the 1870s. PhD Dissertation, University of Manitoba, $297 \mathrm{pp}$.

Hogg, E. H. 1994. Climate and the southern limit of the western Canadian boreal forest. Canadian Journal of Forest Research 24, 1835-1845.

Hunt, C. P., Moskowitz, B. M., and Banerjee, S. K. 1995: Magnetic properties of rocks and minerals. Rock Physics and Phase Relations. A Handbook of Physical Constants: AGU Reference Shelf, 189-204.

Jacobson, H. A., and Engstrom, D. R. 1989. Resolving the chronology of recent lake sediments: an example from Devil's Lake, North Dakota. Journal of Paleolimnology 2, 81-97. 
Laird, K. R., Michels, A., Stuart, C. T. L., Wilson, S. E., Last, W. M., and Cumming, B. F. 2007. Examination of diatom-based changes from a climatically sensitive prairie lake (Saskatchewan, Canada) at different temporal perspectives. Quaternary Science Reviews 26: 3328-3343

Lee, E. J., Kenkel, N. C., and Booth, T. 1996. Pollen deposition in the boreal forest of westcentral Canada. Canadian Journal of Botany 74, 1265-1272.

Matile, G. L. D., and Keller, G. R. 2006. Surficial Geology Compilation Map Series (SGCMS) / GIS Map Gallery / Manitoba Geological Survey / http://www.gov.mb.ca/stem/mrd/geo/gis/surfgeomap.html

MacDonald, G. M., and Case, R. A. 2000. Biological evidence of multiple temporal and spatial scales of hydrological variation in the western interior of Canada. Quaternary International 67: 133-142.

McAndrews, J. H. 1988. Human disturbance of North American forests and grasslands: the fossil pollen record. In Huntley, B., and Webb, T. III, editors, Vegetation History, Kluwer Academic Publishers, 673-697

McKnight, R. 2000. Determination of silica in waters by flow injection analysis. Quikchem Method 10-114-21-1A. Lachat Instruments.

Nelson, D. M., Hu, F. S., Grimm, E. C., Curry, B. B., and Slate, J. E. 2006. The influence of aridity and fire on Holocene prairie communities in the eastern prairie peninsula. Ecology 87, 2523-2536.

Nelson, D., Hu, F. S., Tian, J., Stefanova, I., and Brown, T. A. 2004. Response of $C_{3}$ and $C_{4}$ plants to middle-Holocene climatic variation near the prairie-forest ecotone of Minnesota. Proceedings of the National Academy of Sciences of the United States of America 101, 562-567.

Ritchie, J. C. 1969. Absolute pollen frequencies and ${ }^{14} \mathrm{C}$ age of a section of Holocene lake sediment from the Riding Mountain area of Manitoba. Canadian Journal of Botany 47: 1345-1349.

Ritchie, J. C., and Harrison, S. P. 1993. Vegetation, lake levels, and climate in western Canada during the Holocene. In Wright, H. E. Jr., Kutzbach, J. E., Webb, T. III, Ruddiman, W. F., Street-Perrott, F. A., and Bartlein, P. J., editors, Global Climates since the Last Glacial Maximum, University of Minnesota Press, 401-414.

Ritchie, J. C., and Lichti-Federovich, S. 1968. Holocene pollen assemblages from the Tiger Hills, Manitoba. Canadian Journal of Earth Sciences 5, 873-880. 
Running, G. L., Havholm, K. G., Boyd, M., and Wiseman, D. J. 2002. Holocene stratigraphy and geomorphology of Flintstone Hill, Lauder Sandhills, Glacial Lake Hind Basin, Southwestern Manitoba. Géographie physique et Quaternaire 56: 291-303.

Scott, G. A. J. 1995. Canada's Vegetation: A World Perspective. McGill-Queen's University Press.

Sims, P. L., and Risser, P. G. 2000. Grasslands. In Barbour, M. G, and Billings, W. D., editors, North American Terrestrial Vegetation, Cambridge University Press, 323-356.

Strong, W. L., and Hills, L. V. 2005. Late-glacial and Holocene paleovegetation zonal reconstruction for central and north-central North America. Journal of Biogeography 32, 1043-1062.

Stuiver, M., Reimer, P. J., Bard, E., Beck, J. W., Burr, G. S., and Hughen, K. A. 1998. INTCAL98 radiocarbon age calibration 24,000-0 cal BP. Radiocarbon 40, 1041-1083.

Stuiver, M., Reimer, P. J., and Reimer, R. 1999. CALIB Radiocarbon Calibration (HTML version 4.2). http://depts.washington.edu/qil/calib/.

Stuiver, M., Reimer, P. J., and Reimer, R. 2005. CALIB Radiocarbon Calibration (HTML version 5.0.2). http://calib.qub.ac.uk/calib/

Transeau, E. N. 1935. The Prairie Peninsula. Ecology 16, 423-437.

Triplett, L. 2002. Standard Operating Procedures for Grain Size Analysis Sample Preparation. http://Irc.geo.umn.edu/gz.pdf.

Umbanhowar, C. E. Jr., Camill, P., Geiss, C. E., and Teed, R. 2006. Asymmetric vegetation responses to mid-Holocene aridity at the prairie-forest ecotone in south-central Minnesota. Quaternary Research 66, 53-66.

Umbanhowar, C. E., Jr., and McGrath, M. J. 1998. Experimental production and analysis of microscopic charcoal from wood, leaves, and grass. The Holocene 8, 341-346.

Vance, R. E., Beaudoin, A. B., and Luckman, B. H. 1995. The paleoecological record of 6 ka BP climate in the Canadian Prairie Provinces. Géographie physique et Quaternaire 49, 8198.

Webb, T. III, Ruddiman, W. F., Street-Perrott, F. A., Markgraf, V., Kutzbach, J. E., Bartlein, P. J., Wright, H. E. Jr., and Prell, W. L.. 1993. Climatic changes during the past 18,000 years: Regional syntheses, mechanisms, and causes. In Wright, H .E., Jr., Kutzbach, J. E., Webb, T. III, Ruddiman, W. F., Street-Perrott, F. A., and Bartlein, P. J., editors, Global Climates since the Last Glacial Maximum, University of Minnesota Press, 514-535.

Weir, T. R. 1983. Atlas of Manitoba. Department of Natural Resources. 
Wolfe, S. A., Muhs, D. R., David, P. P. and McGeehin, J. P., 2000. Chronology and geochemistry of late-Holocene eolian deposits in the Brandon Sand Hills, Manitoba, Canada. Quaternary International, 67: 61-74.

World Wildlife Fund. 1999. Terrestrial ecoregions of North America: a conservation assessment. Island Press.

Wright, H. E. Jr., Mann, D. H., and Glaser, P. H. 1984. Piston corers for peat and lake sediments. Ecology 65, 657-659.

Wright, H. E. Jr., Stefanova, I., Tian, J., Brown, T. A., and Hu, F. S. 2004. A chronological framework for the Holocene vegetational history of central Minnesota: the Steel Lake pollen record. Quaternary Science Reviews 23, 611-626. 
Table 1: AMS radiocarbon dates from Jones Lake and Mallard Pond, Manitoba, Canada.

\begin{tabular}{|c|c|c|c|c|c|}
\hline CAMS \# & $\begin{array}{l}\text { Depth } \\
\text { (cm) }\end{array}$ & ${ }^{14} \mathrm{C}$ yr BP & $\begin{array}{l}+/- \\
\text { error }\end{array}$ & $\begin{array}{l}\text { Calibrated age } \\
\text { (cal yr BP) }\end{array}$ & Material dated \\
\hline \multicolumn{6}{|c|}{ Jones Lake } \\
\hline 105832 & 428 & 345 & 30 & 390 & Charcoal \\
\hline 103308 & 495.5 & 995 & 35 & 920 & Charcoal \\
\hline 103309 & 557 & 1645 & 35 & 1540 & Charc. Frags, Seeds ${ }^{1}$, Leaf Frag. \\
\hline 103310 & 607 & 2065 & 35 & 2030 & Charcoal \\
\hline 103311 & 797 & 3025 & 40 & 3230 & Charcoal \\
\hline 105121 & 924 & 3495 & 35 & 3760 & Charcoal \\
\hline 105122 & 1054 & 3800 & 40 & 4180 & Charcoal \\
\hline 105123 & 1164 & 4455 & 50 & 5100 & Charcoal \\
\hline 109284 & 1264.4 & 6230 & 45 & 7120 & Charcoal \\
\hline 109285 & 1387.4 & 7250 & 60 & 8060 & Charcoal \\
\hline 97116 & 1488.4 & 8320 & 40 & 9350 & Charcoal \\
\hline 97117 & 1555.4 & 9940 & 70 & 11360 & Charcoal \\
\hline \multicolumn{6}{|c|}{ Mallard Pond } \\
\hline 105833 & 1082 & 1645 & 35 & 1550 & Charcoal Fragments \\
\hline 105116 & 1145 & 1905 & 40 & 1850 & Charcoal Fragments \\
\hline 103810 & 1189 & 2220 & 35 & 2230 & Cone Scale \\
\hline 107018 & 1242 & 2535 & 40 & 2590 & Charcoal Fragments \\
\hline 107019 & 1292 & 2980 & 60 & 3160 & Charcoal Fragments \\
\hline 105118 & 1364 & 3700 & 50 & 4040 & Charcoal and Leaf Fragments \\
\hline 105117 & 1395 & 4295 & 40 & 4860 & Charcoal and Leaf Fragments \\
\hline 105119 & 1443 & 4565 & 40 & 5180 & Charcoal Fragments \\
\hline 105120 & 1491 & 5840 & 60 & 6650 & Charc. Frags \& Polygonum Seeds \\
\hline 93676 & 1528.5 & 6325 & 40 & 7260 & Charcoal Fragments \\
\hline 97115 & 1565.5 & 7960 & 40 & 8840 & Charcoal Fragments \& Seeds \\
\hline
\end{tabular}


FIGURE 1: Map of Manitoba, showing vegetation formations (modified from Weir 1983) and location of Jones and Mallard Lakes. Locations of E and Glenboro Lakes (Ritchie and LichtiFederov, 1968; Ritchie 1969) are discussed in text and included for reference.

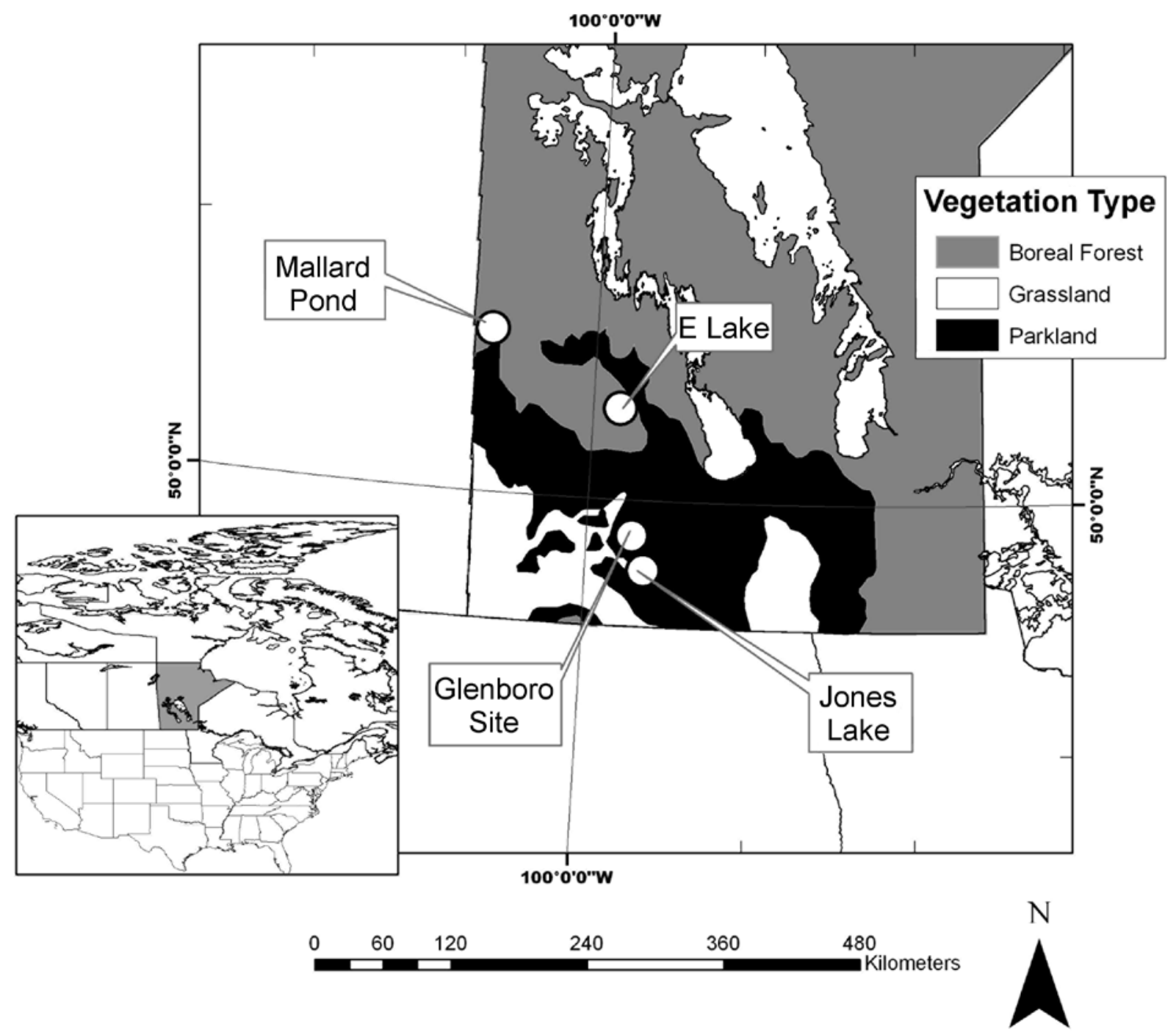


FIGURE 2: Calibrated age-depth models for (a) Jones and (b) Mallard Lakes based on 210Pb dating of surface sediments and calibrated AMS ${ }^{14} \mathrm{C}$ dating of charcoal or plant macrofossils (Table 1).
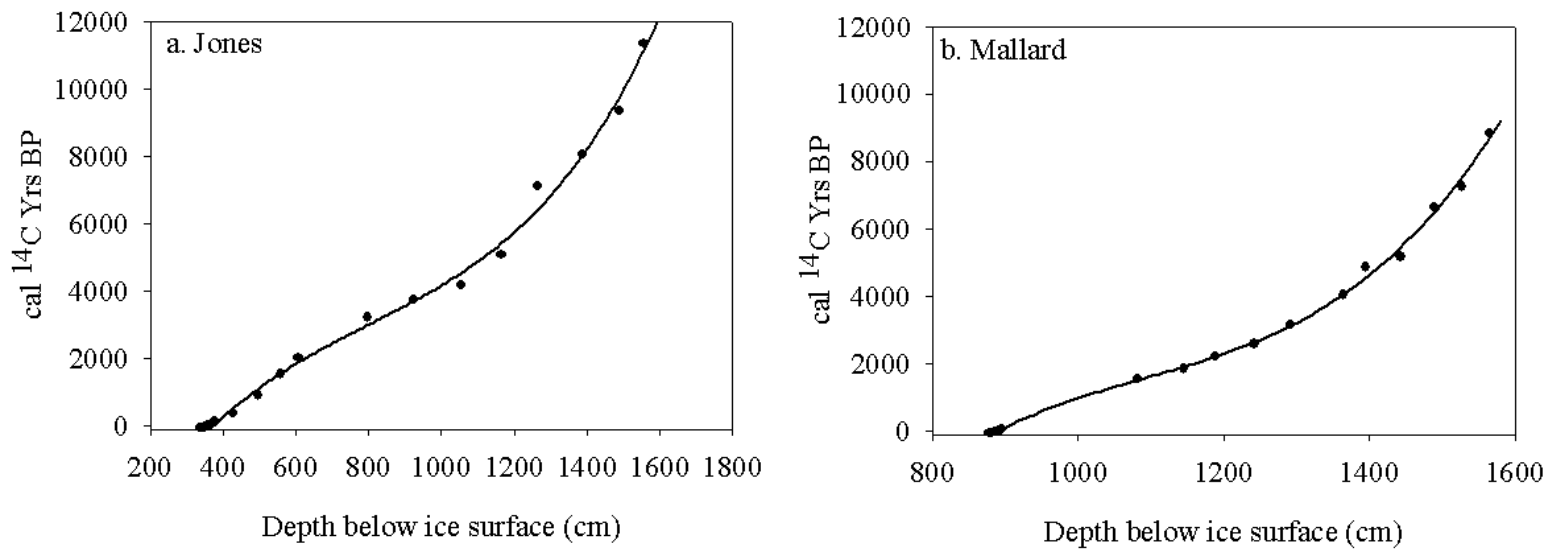
FIGURE 3: Summary of major pollen taxa for Jones Lake. Data are expressed as percentage of main sum. Pollen zones were determined by optimal (nonbinary) splitting of the information content of pollen percentages for taxa that were at least $5 \%$ of the total sum of terrestrial pollen and spore types for one or more levels by psimpoll (Bennett, 1994).

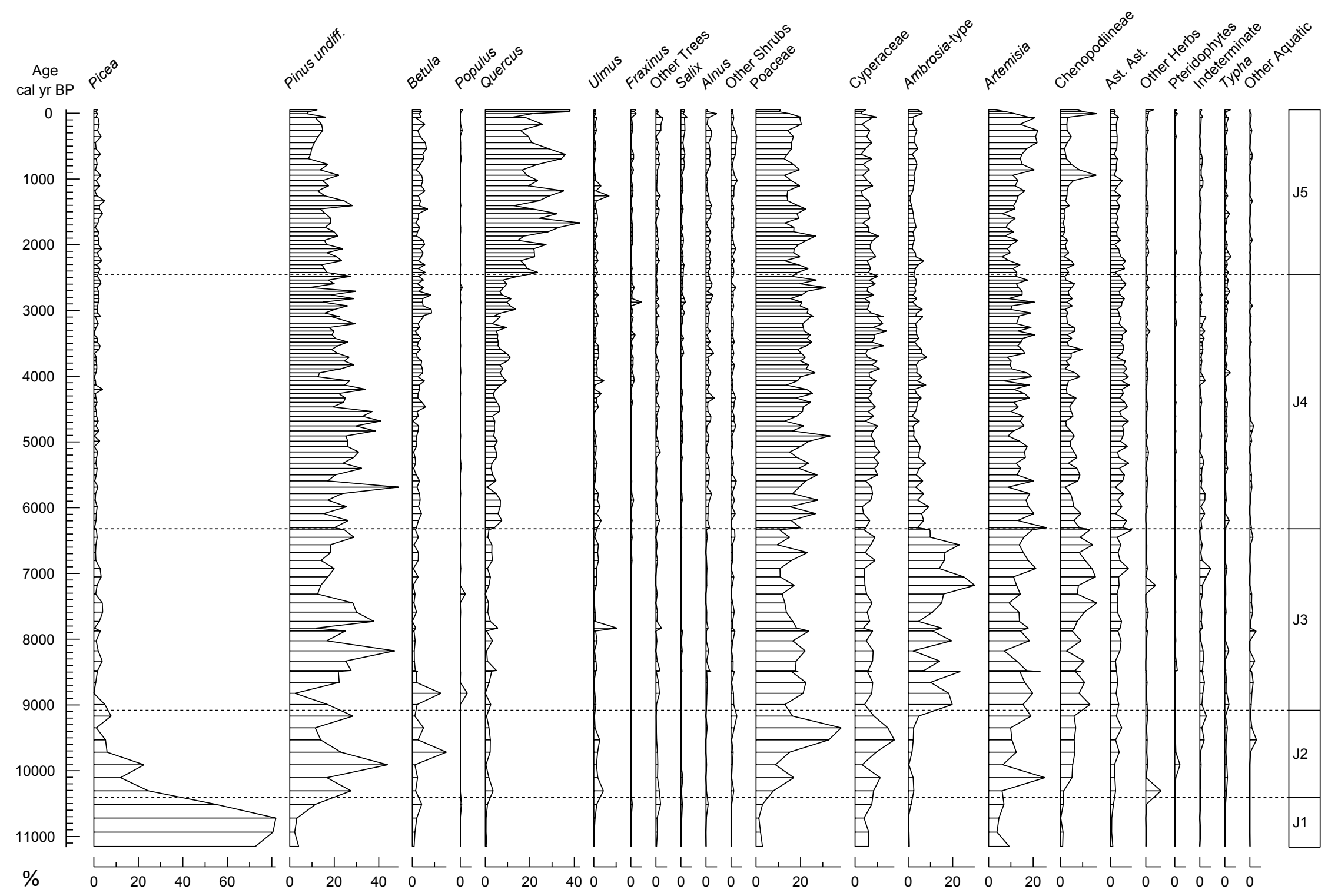

Data are available at https://www.neotomadb.org/

R. Teed, C.E. Umbanhowar, \& P. Camill. 2009. The Holocene 19(6), 937-948. DOI: $10.1177 / 0959683609336569$ 
FIGURE 4: Profiles of sediment magnetics, sediment composition, lake productivity proxies, pollen, and charcoal for Jones Lake. Isothermal remanent magnetization (IRM) and anhysteretic magnetic remanence (ARM) $(a, b)$ are measures of the concentration of magnetic particles (increases with IRM) and particle size (decreases as ARM:IRM ratio increases). Sediment composition includes LOI (c) organic, carbonate, and residual inorganic fractions, and mean grain size of terriginous materials. Productivity proxies include percent biogenic silica (d), total phosphorus (e) and percent organic phosphorus (f). Vegetation ( $\mathrm{g}$ ) is given as percentage (as fraction of main sum) trees, shrubs, herbaceous, and fire severity is expressed in terms of charcoal area (h) and influx (i). Pollen zones were determined by optimal (nonbinary) splitting of the information content of pollen percentages for taxa that were at least $5 \%$ of the total sum of terrestrial pollen and spore types for one or more levels by psimpoll (Bennett, 1994). The ARM:IRM ratio from the uppermost sample is not shown here: 0.87.

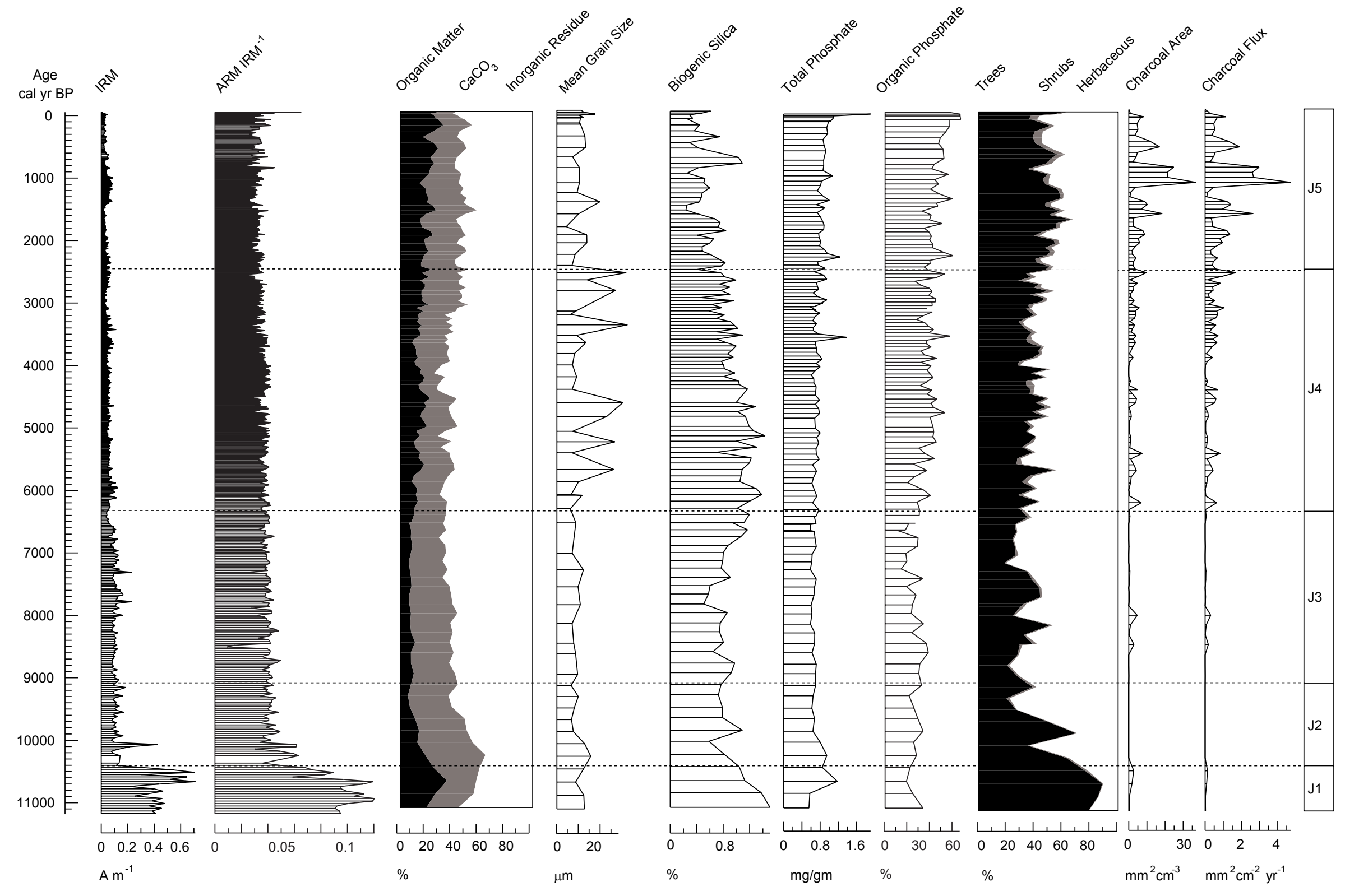

R. Teed, C.E. Umbanhowar, \& P. Camill. 2009. The Holocene 19(6), 937-948. DOI: $\underline{10.1177 / 0959683609336569}$ 
FIGURE 5: Summary of major pollen taxa for Jones Lake. Data are expressed as percentage of main sum. Pollen zones were determined by optimal (nonbinary) splitting of the information content of pollen percentages for taxa that were at least $5 \%$ of the total sum of terrestrial pollen and spore types for one or more levels by psimpoll (Bennett, 1994).

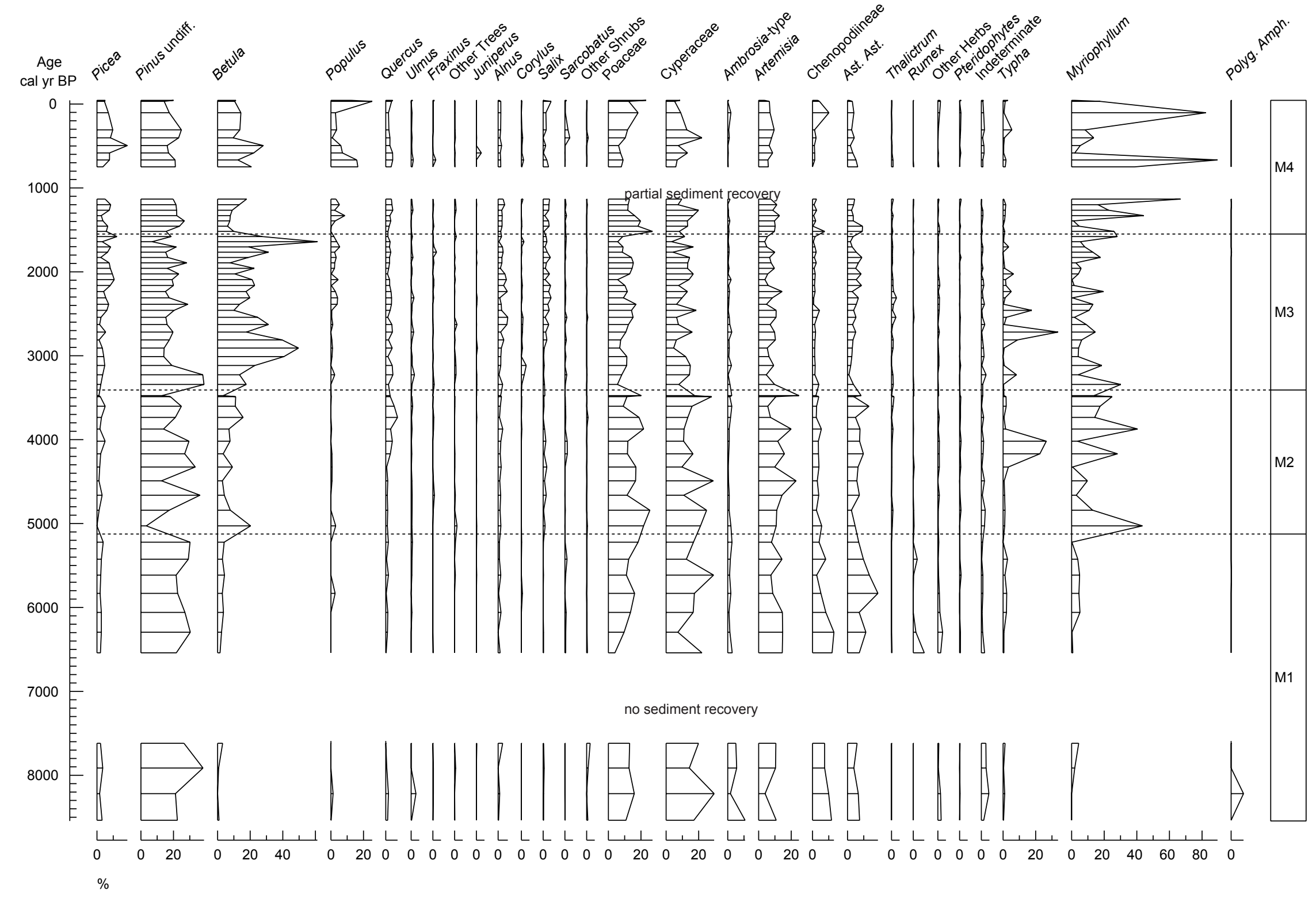

Data are available at https://www.neotomadb.org/

R. Teed, C.E. Umbanhowar, \& P. Camill. 2009. The Holocene 19(6), 937-948. DOI: $\underline{10.1177 / 0959683609336569}$ 
FIGURE 6: Profiles of sediment magnetics, sediment composition, lake productivity proxies, pollen, and charcoal for Mallard Lake. Isothermal remanent magnetization (IRM) and anhysteretic magnetic remanence (ARM) $(a, b)$ are measures of the concentration of magnetic particles (increases with IRM) and particle size (decreases as ARM:IRM ratio increases). Sediment composition includes LOI (c) organic, carbonate, and residual inorganic fractions, and mean grain size of terriginous materials. Productivity proxies include percent biogenic silica (d), total phosphorus (e) and percent organic phosphorus (f). Vegetation ( $g$ ) is given as percentage (as fraction of main sum) trees, shrubs, herbaceous, and fire severity is expressed in terms of charcoal area (h) and influx (i). Pollen zones were determined by optimal (nonbinary) splitting of the information content of pollen percentages for taxa that were at least $5 \%$ of the total sum of terrestrial pollen and spore types for one or more levels by psimpoll (Bennett, 1994).

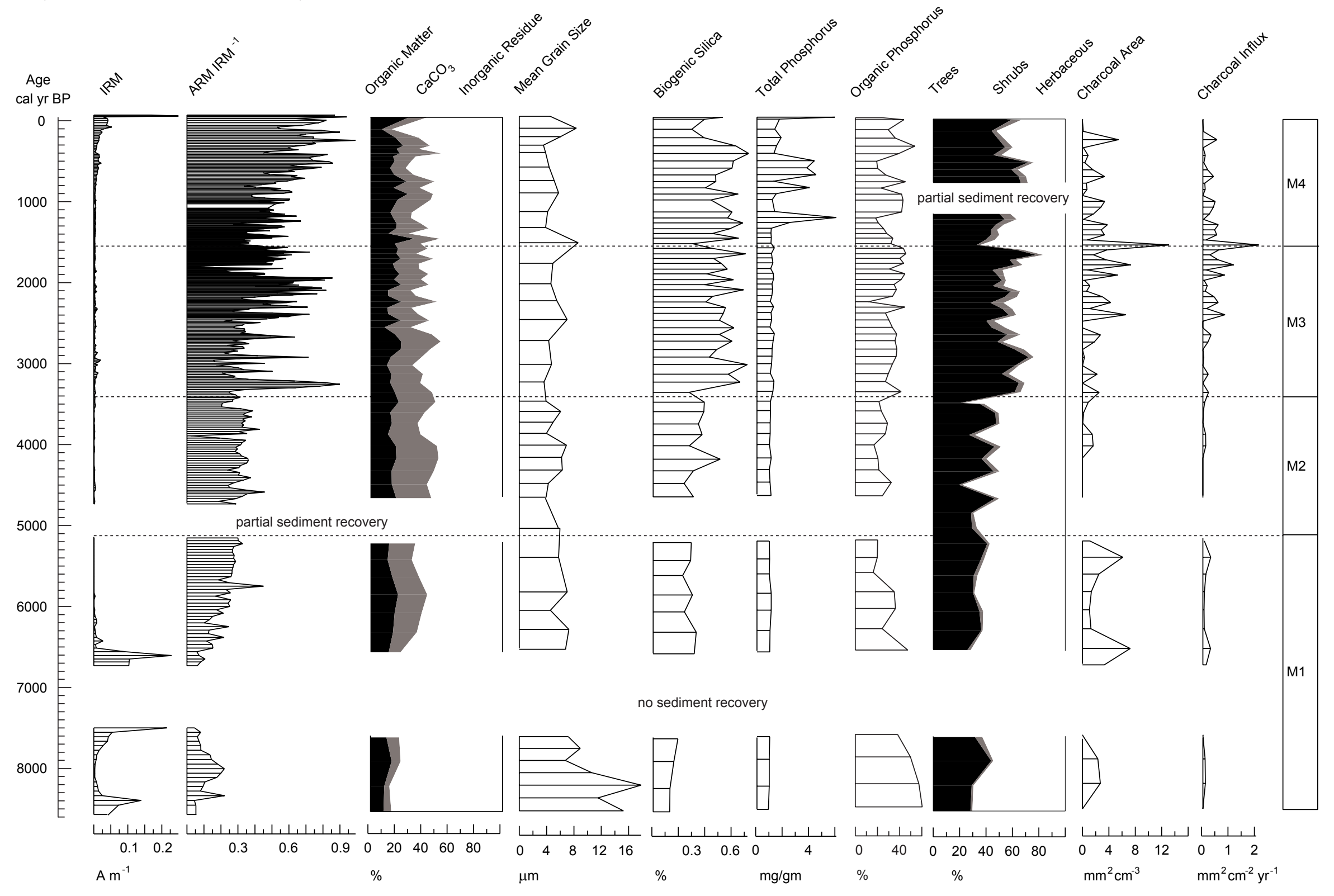

R. Teed, C.E. Umbanhowar, \& P. Camill. 2009. The Holocene 19(6), 937-948. DOI: $10.1177 / 0959683609336569$ 
FIGURE 7: Comparison of pollen zones at Jones Lake and Mallard Pond (this study) with vegetation records from the Glenboro site (Ritchie and Lichti-Federovich, 1968) and E Lake (Ritchie, 1969). The zone labels are those defined by the authors, but zones are not necessarily the same as the general vegetation types being discussed in the text. Note that dates for the Glenboro site and E Lake are based on a linear interpolation (Grimm, 1999) between radiocarbon dates from bulk sediments and dates from correlation with other sites. These were calibrated using CALIB 5.0.2 (Stuiver et al., 2005). The E Lake dates were partially adjusted for bias caused by the inclusion of older carbon by Ritchie (1969) in the text of his paper. However, radiocarbon dates from these bulk sediment samples may be considerably older than AMS radiocarbon dates from terrestrial macrofossils if there has been inclusion of older carbon from watershed soils or sediments into the lake sediments (Cohen, 2003).

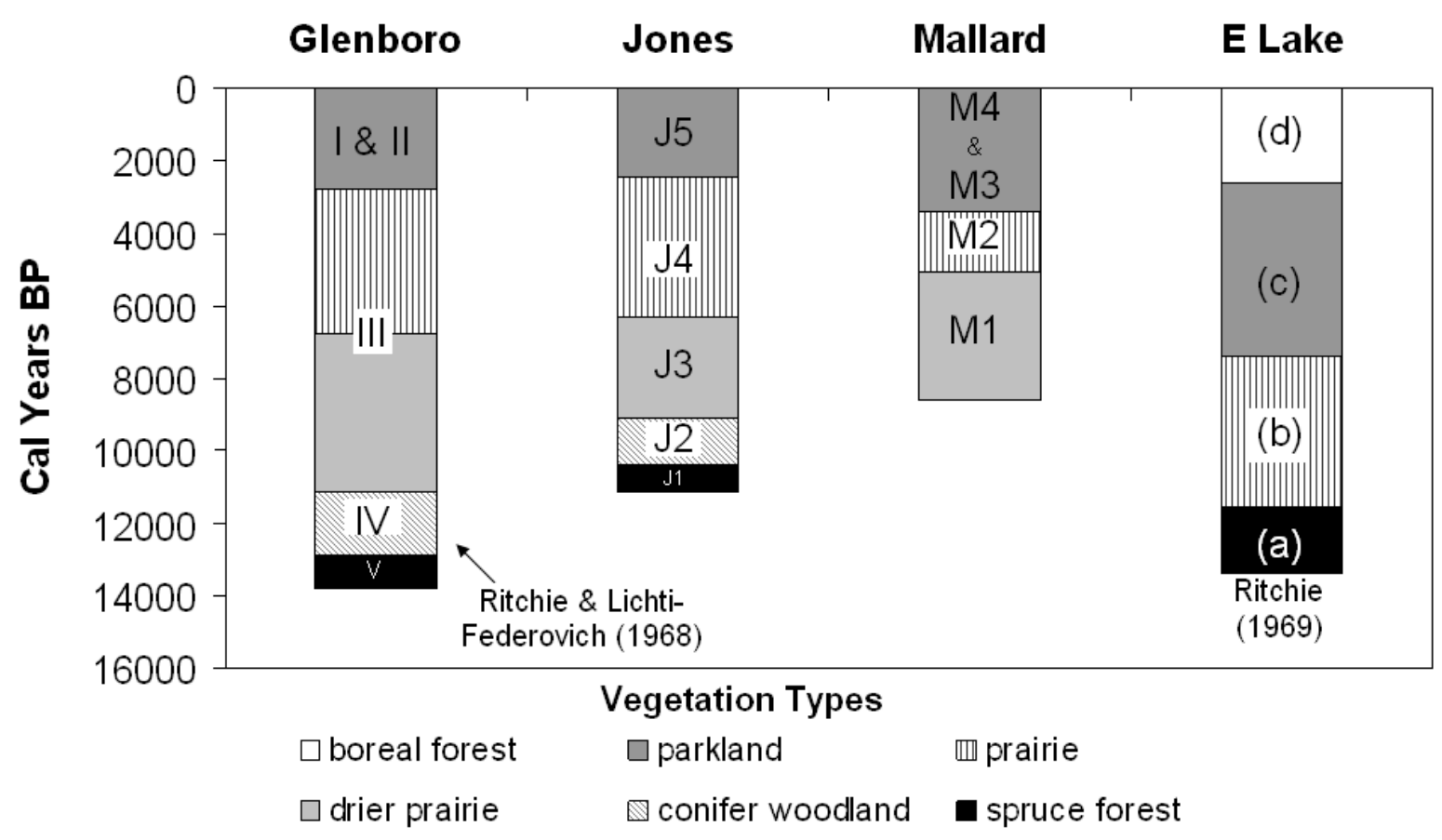

